\title{
A ETNICIDADE NA SALA DE AULA: O USO DE ADAPTAÇÕES DE CLÁSSICOS DA ANTI- GUIDADE
}

\author{
Renata Cardoso de Sousa ${ }^{1}$
}

\begin{abstract}
Existe, por exemplo, o gosto pela viagem - um prazer muito especial, que não deve ser confundido com fuga, evasão ou escapismo. É o gosto pela imersão no desconbecido, pelo conbecimento do outro, pela exploração da diversidade. A satisfação de se deixar transportar para outro tempo e outro espaço, viver outra vida com experiências diferentes do cotidiano (MACHADO, 2009, p. 19 e 20).
\end{abstract}

\begin{abstract}
Resumo: Propomos pensar como é possível trabalhar o tema da etnicidade e do etnocentrismo na sala de aula a partir do uso de adaptações de clássicos da Antiguidade. Para tal, primeiramente, é necessário estabelecer alguns critérios para a utilização dessa literatura, que ainda gera debates acerca da sua proficuidade, bem como conceituar a etnicidade. Partiremos dos conceitos de etnicidade (proposto por Fredrik Barth) e identidade-alteridade (de Marc Augé), para depois nos debruçarmos sobre propostas de trabalho com algumas adaptações selecionadas.

Palavras-chave: Ensino de História; adaptações literárias; etnicidade.
\end{abstract}

Objetivamos, nesse artigo, pensar algumas questóes concernentes tanto ao Ensino de História quanto à validade da utilização de adaptações de clássicos da Antiguidade em sala de aula como forma de estímulo à leitura. Dentre essas questóes, estão: a) Por que tratar o tema da etnicidade e do etnocentrismo em sala de aula?; b) Por que recorrer à Antiguidade para (re)pensar a etnicidade? c) Por que utilizar adaptações em sala de aula, se podemos mediar a leitura do clássico com os alunos?

Para tal proposta, primeiro propomos pensar acerca do próprio conceito e de sua importância dentro do contexto escolar, para depois pensarmos o

1 Professora Doutoranda do Programa de Pós-graduação em História Comparada (PPGHC-UFRJ). Orientada pelo Prof. Dr. Fábio de Souza Lessa. Bolsista CAPES. E-mail: renatacardoso1990@gmail.com. 
conceito na Antiguidade grega. Em seguida, discutiremos a proficuidade das adaptaçóes e definiremos mesmo o que seriam elas. No final, propomos algumas soluçóes para o trabalho com o conceito de etnicidade utilizando adaptaçóes da Odisseia em sala de aula, com exemplos práticos.

\section{i.o "A História é decoreba" ou "A História ensina fatos do PASSADO, NÃo do PRESENTE" ‘ O SENSO COMUM E O ENSINO dE História}

Quem é professor de História, em algum momento já deve ter ouvido essas duas frases de alunos, pais de alunos ou até mesmo de diretores ou coordenadores. Entretanto, quando nos deparamos com as pesquisas no âmbito do Ensino de História (e na área de ensino em geral), percebemos o quanto essas duas visões estão ultrapassadas. Os próprios Parâmetros Curriculares Nacionais do Ensino de História (PCN) desconstroem essa ideia:

A construção de noções interfere nas estruturas cognitivas do aluno, modificando a maneira como ele compreende os elementos do mundo e as relações que esses elementos estabelecem entre si. Isso significa dizer que quando o estudante apreende uma noção, grande parte do que ele sabe e pensa é reorganizado a partir dela. Na medida em que o ensino de História the possibilita construir noções, ocorrem mudanças no seu modo de entender a si mesmo, os outros, as relaçóes sociais e a História. Os novos domínios cognitivos do aluno podem interferir, de certo modo, nas suas relações pessoais e sociais e nos seus compromissos e afetividades com as classes, os grupos sociais, as culturas, os valores e as gerações do passado e do futuro. (BRASIL, 1998, p. 35).

Sendo assim, o Ensino de História deixa de se basear na mera reprodução dos fatos históricos e a cobrança deles nas provas: ele começa a elaborar uma série de objetivos (como os próprios objetivos gerais do PCN - BRASIL, 1998, p. 43) que buscam a utilização da História para construir pessoas críticas, capazes de utilizar o arcabouço conceitual que possuem para discutir acerca da sua própria realidade e também modificá-la.

Fato é que, frequentemente, nos deparamos com esses dois estereótipos do Ensino de História, os quais dificultam (mas não impossibilitam) o avanço da aplicação da pesquisa à prática escolar (algo também tão caro ao $\mathrm{PCN}^{2}$ ). Ainda nos deparamos com muitos estereótipos nos livros didáticos

2"Nas últimas décadas, por diferentes razões, nota-se uma crescente preocupação dos professores do ensino fundamental em acompanhar e participar do debate historiográfico, criando 
de História (como a "Idade Média trevosa" ou a "invasão dos bárbaros"), bem como às vezes somos pressionados, como professores, a fazer provas que são meras verificações e não avaliações (LUCKESI, 2008, p. 93). A História é para ser compreendida, não decorada por meio de um questionário. E ela é para ser compreendida não para servir de exemplo, mas para fazer refletir acerca do nosso próprio presente e nos fazer entender como chegamos ao ponto em que estamos.

A avaliação, nesse sentido, deixaria de se ater apenas à verificação de um conteúdo fatual inculcado, mas traria situações-problema e questões culturais, do próprio cotidiano e da realidade nacional e internacional para que o aluno pudesse aplicar os conhecimentos acerca do estudo da História. Ele demonstraria que, de fato, aprendeu a pensar historicamente e a aplicar esse pensamento à sua realidade, e não apenas decorou o conteúdo para passar de ano.

Isso não significa abandonar o fato histórico, mas, sobretudo, utilizá-los para pensar acerca do presente e instigar o contato com a alteridade por parte do educando, a fim de que ele possa, assim, reconhecer sua própria identidade e não desrespeitar ou repudiar as maneiras pelas quais o Outro constrói sua própria identidade. Esse é outro ponto (o respeito às alteridades) que toca o PCN (BRASIL, 1998, p. 35 e 36), de modo não a simplesmente "formar cidadãos brasileiros", como era a proposta majoritária no Ensino de História (NADAI, 2017, p. 30), mas formar pessoas que têm o respeito como valor máximo.

Em tempos sombrios, nos quais cada vez mais vemos um retrocesso em relação ao respeito aos direitos humanos e às pessoas que pensam/agem diferente de nós, nos quais a liberdade de expressão é confundida com liberdade de opressão e liberdade de ofensa, é mister que o exercício da alteridade seja um dos nortes da Educação. Para isso, é preciso compreender alguns conceitos, como os de identidade, alteridade, etnicidade e etnocentrismo. É por esse motivo que é importante, na sala de aula, não só "passarmos todo o conteúdo", mas também fazer os educandos refletirem acerca dos conceitos que perpassam a História.

As conceituações e as noções, em vez de serem trabalhadas por meio de suas características genéricas, assumem especificações históricas, possibilitando

aproximações entre o conhecimento histórico e o saber histórico escolar. Reconhece-se que o conhecimento científico tem seus objetivos sociais e é reelaborado, de diversas maneiras, para o conjunto da sociedade. Na escola, ele adquire, ainda, uma relevância específica quando é recriado para fins didáticos" (BRASIL, 1998, p. 30). 
o diálogo entre os sujeitos que falam pelos documentos legados ao presente e aqueles que os interpretam. Nesse sentido, é importante recuperar na História a bistoricidade dos conceitos, sua relação com a interpretação e categorização de fenômenos em contextos temporais especificos. (BRASIL, 1998, p. 82).

"Revolução", "descobrimento", "nacionalismo", "identidade", "alteridade" e "etnicidade" são exemplos de conceitos que estão presentes em várias épocas, em várias sociedades, e inclusive na nossa própria sociedade. Além disso, esses conceitos são passíveis de interpretações diversas, revelando a reflexão acerca deles bastante profícua para o aluno entender melhor o que é a História e o que é o processo histórico. No entanto, é preciso que o professor saiba lidar com esses conceitos:

Se o professor não tiver clareza sobre o sentido e aplicação de conceitos como cidadania, diferença, semelhança, permanência, transformação, questionamento, convivência e outros que compóem o vocabulário dos programas e materiais de ensino, como será possível conduzir ou mesmo participar de um projeto de aprendizagem? (MICELI, 2017, p. 40 grifos do autor).

Por isso é necessário que, antes de entrarmos no mérito do trabalho com o conceito de etnicidade, compreendê-lo melhor, sobretudo no que tange a Grécia Antiga, nosso foco de análise.

\subsection{O QUE É A ETNICIDADE?}

Essa é uma pergunta sem resposta definitiva: desde os anos 1960 se tenta fechar o conceito de etnicidade, mas sem sucesso, uma vez que essas tentativas, como a de Burgess em 1978, de se cristalizar de modo estanque o conceito acaba mais por generalizá-lo do que defini-lo (POUTIGNAT; STREIFFFENART, 2011, p. 86). Contudo, precisamos considerar que a etnicidade, diferentemente da alteridade, tem relação intrínseca com a origem em comum de um povo conectada com um território específico.

É Fredrik Barth quem estabelece um conceito de etnicidade bastante próximo do que entendemos por etnicidade: o autor afirma que "a identidade étnica é associada a um conjunto cultural específico de padróes valorativos" (BARTH, 2011, p. 209). A etnicidade é, desse modo, relacional: é a partir do contato com os Outros que ela se define e é a partir desse contato que ela também se mantém. "O campo de pesquisa designado pelo conceito de etnicidade", 
afirmam Philippe Poutignat e Jocelyne Streiff-Fenart (2011, p. 141), é aquele que estuda "os processos variáveis e nunca terminados pelos quais os atores identificam-se e são identificados pelos outros na base de dicotomizações Nós/Eles, estabelecidas a partir de traços culturais que se supóe derivados de uma origem comum e realçados nas interaçóes raciais".

Além disso, Barth enfoca justamente nos limites do grupo étnico, a partir da definição de fronteira étnica: esse grupo não é estático, mas muda conforme entra em contato com outros grupos, justamente a fim de manter a sua própria etnicidade. Assim, "os traços culturais que demarcam os limites do grupo podem mudar, e a cultura pode ser objeto de transformações, sem que isso implique o esvaziamento da solidariedade étnica" (LUVIZOTTO, 2009, p. 31). Segundo Barth, "se um grupo conserva sua identidade quando os membros interagem com outros, isso implica critérios para determinar a pertença e meios para tornar manifesta a pertença e a exclusão" (BARTH, 2011, p. 195).

Por colocar em jogo essa relação entre o "Nós" e o "Eles", é imprescindível aliar às análises étnicas o par conceitual identidade/alteridade. Seguimos o norte teórico do antropólogo Marc Augé, que não enxerga esses dois conceitos de maneira diametralmente oposta, mas como um par complementário: a identidade não existe sem definições de alteridade e vice-versa (AUGÉ, 1998, p. 28). Ele trabalha, especificamente, com a questão da alteridade nos mitos, na mídia e no contato entre os colonizadores e os nativos e procuramos reapropriar proficuamente seu arcabouço conceitual para a análise do nosso objeto histórico-discursivo.

$\mathrm{O}$ conceito de alteridade tem uma origem marcadamente antropológica, assim como o de etnicidade: o contato com outras culturas é imbuído de choques. No entanto, Charles Mugler aponta que a noção de Outro retrocede mais no tempo do que sua etimologia: alteridade deriva do latim alter, outro. Mas, em Homero mesmo, já podemos ver o papel que o vocábulo állos, "outro", desempenha para definir o dessemelhante (MUGLER, 1969, p. 1). O próprio conectivo adversativo "allá", que, até hoje, significa "mas" para os gregos, tem uma origem nesse vocábulo (BAILLY, 2000, p. 82; CHANTRAINE, 1968, pp. 63-64): o "outro" assemelha-se ao "mas", ao adverso.

Os estudos de etnicidade em relação à Antiguidade grega são recentes e encontraram em Edith Hall, Jonathan Hall e Irad Malkin grande expressão. Este último, sobretudo, adentra mais ainda o tema, retirando das Guerras Greco-Pérsicas (490-479 a.C.) o suposto mérito de ter contribuído para o desenvolvimento de relaçóes étnicas entre os gregos e seus Outros, se debruçando sobre a Odisseia de Homero. 
No nosso trabalho de doutorado, objetivamos incluir a Ilíada no centro das discussões acerca da etnicidade também, bem como pensar a construção de um processo discursivo em torno da etnicidade e da identidade-alteridade em Homero, Ésquilo, Sófocles e Eurípides, sendo o primeiro o arquitexto desses três últimos. Objetivamos analisar como as fronteiras étnicas entre os gregos e seus Outros (e, posteriormente, entre a pólis ateniense e as demais, sobretudo as peloponésicas) são construídas desde as epopeias homéricas, inclusive a Ilíada, no bojo da relação de inimizade na guerra entre troianos e aqueus.

$\mathrm{Na}$ Odisseia, de fato, as relações étnicas entre os gregos e os seus Outros ficam mais evidentes, por conta dos enfrentamentos de Odisseu com a alteridade em sua viagem de retorno a Ítaca. Embora ele se depare com diversos povos (como os cícones, os lestrigóes, os lotófagos e até mesmo os feácios, que, embora muito parecidos com os gregos em sua cultura, resistem à amizade ritual, elemento distintivo entre eles e os bárbaros no processo discursivo helênico) e pessoas (como Circe e Calipso, que são feiticeiras) que destoam do ideal de conduta e civilização gregas, é no episódio dos ciclopes que as marcas étnicas entre os gregos e seus Outros ficarão mais evidentes.

Esse episódio é tão marcante que ele não se restringe apenas ao Canto IX, no qual ele é narrado: em vários Cantos da Odisseia, o Cíclope reaparece, mesmo que seja apenas mencionado (HOMERO, Odisseia, I, vv. 69-73; II, vv. 19-20; X, vv. 200 e 435; XII, vv. 209-212; XX, vv. 18-21; XXIII, vv. 312-314). Há uma construção de fronteiras étnicas flagrante nesse encontro, que será explorada, no século V a.C. por Eurípides no seu drama satírico O Cíclope. Eles são descritos do seguinte modo por Odisseu: "destituídos de leis, que confiados nos deuses eternos, não só não cuidam de os campos lavrar, como não

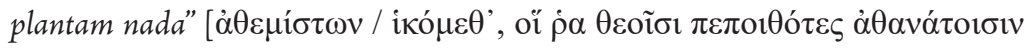

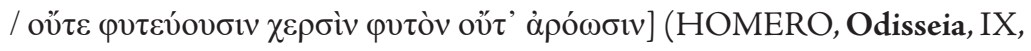
vv. 107-108-grifos nossos).

Polifemo é descrito como um monstro aos olhos do herói: é "gigantesco", "colossal" (pelórios), parece o "pico da cordilheira" (hypsēlôn oréón). Ele não parece um "homem comedor de pão" (andri ge sitophágo): vive sozinho e em estado de athemistía, sem (a-) leis (thémistes), como os outros Ciclopes. O Ciclope nega uma súplica ao não hospedar Odisseu. Isso gera um estado de átē: "a recusa [da súplica] resulta em perdição" (MALTA, 2006, p. 61). A consequência da perdição dele é o vazamento de seu único olho pelo herói da epopeia. Contudo, a própria hýbris (desmedida) de Odisseu ao se vangloriar de tal feito o faz vagar mais pelo mar até conseguir chegar em sua terra natal, Ítaca. 
Para definir o que ele entende por civilização, ele utiliza a definição do Outro: os gregos respeitam a lei porque os Outros não o fazem; a agricultura é a atividade que concede identidade aos gregos porque os Outros não a praticam; o pão é o alimento por excelência dos gregos porque os outros não cozinham o alimento nem o fabricam. E assim por diante. Do mesmo modo nós fazemos: nos orgulhamos de certos traços étnicos, porque são exclusivos a nós, no plano discursivo, não são compartilhados com os Outros.

Para levar essa discussão para a sala de aula, propomos a utilização de adaptações. Para tal, devemos, primeiramente, definir o que entendemos por adaptação e debater acerca das particularidades do uso e estudo delas.

\subsection{CONSIDERAÇốES INICIAIS ACERCA DA RECEPÇÃO DAS ADAPTAÇóes}

Quando vamos ao cinema assistir a um filme baseado em um livro, é comum sairmos frustrados: acabamos chegando à conclusão de que era melhor ter lido o livro somente. Cenas são cortadas ou amalgamadas, os personagens e os cenários nem sempre correspondem à descrição do livro, os diálogos são suprimidos e /ou simplificados. Isso ocorre porque um livro, na verdade, são muitos livros: cada vez que alguém o lê, interpreta e imagina de um jeito os personagens, cenários, cenas, diálogos. É como se fosse um filme interior passando dentro de nossas cabeças. E nenhum cineasta pode estar dentro de nossas cabeças para imaginar como gostaríamos de ver um livro representado nas telas. Afinal, ele mesmo imaginou e criou o mundo do livro em seus pensamentos também.

Além disso, há a questão da narrativa: a dinâmica de um livro é diferente da de um roteiro de cinema, dos planos cinematográficos que existem no discurso fílmico. Seguindo o mesmo raciocínio, podemos pensar acerca das adaptações literárias. $\mathrm{O}$ adaptador leu o livro, imaginou-o: viveu todas aquelas cenas e personagens em sua mente. Entretanto, ele decide não ficar com isso somente para si: ele quer contar para crianças e jovens o que leu, o que imaginou, o que interpretou. E faz a adaptação daquele livro para um público infanto-juvenil, cuja literatura demanda um outro tipo de linguagem, um outro tipo de discurso diferente daquele do livro para um público adulto ou para um público infanto-juvenil de épocas precedentes.

Por conta disso, as adaptações são vistas às vezes como elementos empobrecedores dos clássicos: 
A adaptação das obras clássicas das literaturas nacional e mundial é um tema que desperta polêmica e divide opiniões. Não poderia ser diferente, já que a noção de adaptação não se reduz a um sentido consensual: pode ser associada tanto à noção de "enriquecimento" quanto à de "empobrecimento". Geralmente, argumenta-se que empobreceria as literaturas clássicas em virtude de um processo de atualização e de simplificação, que visaria a atender a públicos especificos, como o infantil e o infanto-juvenil. Por razóes semelhantes, tornaria possível o enriquecimento da formação educativa desses públicos, introduzindo obras de difícil acesso, cuja linguagem seria "complexa" ou temporalmente distante da linguagem com a qual tais leitores estariam habituados. Em ambos os casos, a adaptação seria um conceito amplo que abarcaria as mais diversas formas de linguagem, como bistória em quadrinhos, adaptações cinematográficas e televisivas, desenhos animados, audio-books e os trabalhos em forma de narrativa (AMORIM, 2005, p. 119).

De fato, a adaptação ou releitura daquele livro não será igual ao original, assim como o filme do livro não é igual ao livro; afinal, a proposta é diferente e os autores são diferentes. "A reescritura proposta não é simplesmente a'mesma coisa' que o texto original: há novas associações e outros interesses que são focalizados em novos contextos; são outros alunos e professores que se servirão da obra, num contexto cultural marcado por sua especificidade" (AMORIM, 2005, p. 95). Se nos deparamos com uma adaptação de Miguel de Cervantes, William Shakespeare ou Homero, não são mais Cervantes, Shakespeare e Homero que estão contando aquela história: é o autor da própria adaptação.

Parece óbvio afirmar isso, mas ainda existe uma preocupação em denunciar as dissonâncias entre a adaptação e o original, em detrimento de analisar os porquês daquelas dissonâncias. Os textos clássicos são arquitextos tanto para as adaptaçóes ou releituras quanto para outros textos que não façam referência direta a esses clássicos. Os temas da morte que gera vingança por parte daquele que ainda vive, dos erros do herói que o leva ao amadurecimento, do reconhecimento, da bestialização do ser humano, do ponto fraco do herói são vistos inúmeras vezes na literatura mundial e estão presentes em textos que remontam à Antiguidade Clássica. Deveria ser Robinson Crusoé menos clássico que Odisseu? Ou Robin Hood menos clássico que Páris? Afinal, o tema da permanência em lugares hostis e da descoberta do filho perdido não foram criados por Defoe e Dumas, respectivamente. O próprio Alexandre Dumas, ao escrever seu As aventuras de Robin Hood, estava recriando o personagem das gestas medievais, que foram cristalizadas na escrita tempos depois de terem sido cantadas por séculos. Afinal,

A reescritura proposta não é simplesmente a "mesma coisa" que o texto original: há novas associações e outros interesses que são focalizados em 
novos contextos; são outros alunos e professores que se servirão da obra, num contexto cultural marcado por sua especificidade (AMORIM, 2005, p. 95).

\section{4+o Afinal, O QUE É UMA AdAPTAÇÃo?}

Yves Gambier, logo no início do seu artigo, escreve que a adaptação não teve ainda algum estudo rigoroso ou sistemático, sendo caracterizada, sobretudo, pela "fetichização" do original. "A partir de quando podemos dizer que ela [a adaptação] desfigura, 'trai' o original? Segundo quais normas ela se realiza?” (GAMBIER, 1992, p. 421 e 424).

Objetivamos pensar aqui a adaptação como "histórias recontadas', reescrituras de obras clássicas das literaturas estrangeira e nacional, direcionadas a um público específico, como o infanto-juvenil" (AMORIM, 2005, p. 16). São "textos novos construídos sobre enredos antigos" (FEIJÓ, 2010, p. 42). Essas adaptações não deixam de ser traduções e também releituras, uma vez que estão recontando as histórias originais a fim de torná-las inteligíveis para o sujeito destinatário delas, as crianças e os jovens.

Yves Gambier (1992,p.422), inclusive, critica uma tentativa de diferenciar adaptação de tradução, mostrando que adaptação pode ser concebida como: a) prática de "adicionar e/ou omitir para que o texto de chegada (TC) tenha o 'mesmo efeito' que o texto de partida (TP), dando-se enfoque aos receptores (cultura e língua de chegada)"; b) "fazer obra original a partir de uma outra composta no mesmo sistema de signos ou não"; c) "transformar um texto visando um certo leitorado, por razões e segundo critérios socioeconômicos declarados ou não". Desse modo, inclusive, ele ratifica o conceito de "tradaptação" de Michel Garneau, que viria a eliminar as dicotomias entre a adaptação e a tradução.

O fato de o sujeito destinatário delas serem crianças e jovens não implica que as adaptações sejam exclusivas a esse público, uma vez que adultos podem se tornar sujeitos receptores desses textos. $\mathrm{O}$ contrário também acontece: "Pode até acontecer que a criança, entre um livro escrito especialmente para ela e outro que o não foi, venha a preferir o segundo. Tudo é misterioso, nesse reino que o homem começa a desconhecer desde que o começa a abandonar" (MEIRELES, 2016, p. 19).

As adaptações são "um tipo especial de tradução que envolve[m] seleção de conteúdo - pois resume[m] o enredo - e adequação da linguagem para apresentar a obra escolhida aos jovens de um novo tempo; e assim a tradição 
se perpetua, e se legitima, por meio da renovação" (FEIJÓ, 2010, p. 44). Ela é a "atualização de um discurso literário" (FEIJÓ, 2010, p. 63), pois “[...] as obras tradicionais são reelaboradas ou reinterpretadas à luz das preocupações sociais, morais e literárias de cada momento histórico" (COLOMER, 2017, p. 25).

Em defesa das adaptações, existe uma tendência a se utilizar o conceito de interdiscurso ${ }^{3}$, arquitexto ${ }^{4}$ ou intertexto ${ }^{5}$, oriundos da Análise do Discurso, no intuito de se dizer que, assim como os diversos textos contemporâneos utilizam os clássicos e não são criticados, as adaptações assim também não o devem ser ${ }^{6}$. Contudo, não compartilhamos dessa ideia: os processos interdiscursivos que perpassam os textos não devem ser confundidos ou assemelhados a uma tentativa de tornar inteligível e acessível textos por parte de um público leitor iniciante, como é o caso da adaptação.

As adaptações geralmente (mas não necessariamente) estão atreladas à literatura infanto-juvenil. Foi a partir do século XVIII (quando uma noção de infância começa a surgir) que a literatura infanto-juvenil começa a aparecer ${ }^{7}$, mas com esses fins exclusivamente exemplares: Teresa Colomer (2017, p. 19)

3 Interdiscurso é o conjunto de discursos que antecedem um texto e que o perpassam.

$4 \mathrm{O}$ arquitexto é um texto clássico.

5 Intertexto são os textos que estão presentes em outros textos, seja por meio de citação direta ou referência sem, necessariamente, apontar a autoria original.

6 “Em favor da posição de [Monteiro] Lobato e Nelly [Novaes Coelho], seria interessante ainda argumentar que, se aceitamos o conceito de intertexto, ou seja, essa ideia de que a literatura se constrói como infinito mosaico de citações e influências, mais ou menos remotas, a desconfiança em relação às adaptações deveria ser amenizada. Afinal, se é válida a premissa de que alguns 'clássicos' são obras fundadoras ou canônicas que, ao longo do tempo, se tornam balizas significativas para um dado patrimônio cultural, até que ponto as demais obras produzidas não podem ser compreendidas como contínuas 'adaptações' literárias dessas matrizes?" (CECCANTINI, 2004, p. 86).

ou

“Se aceitarmos a ideia de que os clássicos podem ser classificados como 'textos primeiros' [esse seria o arquitexto] e dar origem, indefinidamente, a novos textos - sempre atualizados com o contexto histórico em que são produzidos, e com público a que se destinam -, então poderemos pensar a adaptação como um procedimento habitual e inerente à renovação da tradição literária, como perpetuação e divulgação dos cânones" (FEIJÓ, 2010, p. 43).

7 Teresa Colomer se refere, aqui, à literatura cujo sujeito destinatário eram as crianças e jovens. Podemos entender melhor essa ideia se analisarmos as três categorias de livros infantis nãointencionais que Cecília Meireles (2016, p. 52) distingue em 1951: 1) a redação escrita das tradições orais (como Perrault e Grimm); 2) os livros escritos para uma determinada criança que depois passaram para uso geral (como La Fontaine); 3 ) livros não escritos para crianças que vieram a cair em suas mãos e dos quais se fizeram adaptações, visando torná-los mais compreensíveis ou adequados ao público infantil. 
afirma que por muito tempo a literatura voltada para crianças e adolescentes focou na exemplaridade e no didatismo. Não que os textos antigos, como Homero, não trouxessem códigos de conduta a serem seguidos (até porque esses textos eram utilizados na formação dos gregos políades), mas eles não foram escritos com tal propósito (MEIRELES, 2016, p. 43).

Colomer (2017, p. 20) defende que a literatura infanto-juvenil está além disso, ela vai: "1) Iniciar o acesso ao imaginário compartilhado por uma determinada sociedade; 2) Desenvolver o domínio da linguagem através das formas narrativas poéticas e dramáticas do discurso literário; 3) Oferecer uma representação articulada do mundo que sirva como instrumento de socialização das novas gerações". A literatura infantil não serve só para ensinar exemplos, mas para tornar a criança um leitor literário (COLOMER, 2017, p. 31).

Para o Ensino da História, a primeira e a terceira função são essenciais para que consideremos o uso dessa literatura na sala de aula. As primeiras adaptações, inclusive, foram feitas por professores (FEIJÓ, 2010, p. 61). Daí a importância da atividade pedagógica para o bom aproveitamento de uma adaptação. Para trabalhar com esse tipo de literatura, é necessário ler o original, a fim de tanto poder selecionar melhor as adaptações aos propósitos da atividade pedagógica proposta quanto trabalhar melhor com a adaptação na sala de aula (FEIJÓ, 2010, p. 150).

No Brasil, as adaptaçóes se popularizaram nos anos 1970, junto com a literatura infanto-juvenil em geral (FEIJÓ, 2010). Entretanto, já no início do século, temos as primeiras adaptações literárias aqui, feitas por Monteiro Lobato. A partir dele, muitos outros autores renomados da literatura brasileira se dedicaram à adaptação: Clarice Lispector, Rubem Braga, Paulo Mendes Campos, Ana Maria Machado. Essa última, inclusive, além de escrever adaptações, refletiu acerca delas em seu Como e por que ler os clássicos universais desde cedo.

Defendemos que a adaptação não pode ser tratada como literatura inferior, uma vez que isso seria tratar a literatura infanto-juvenil do mesmo modo. Além disso, quantas pessoas não começaram a ler os clássicos porque leram boas adaptações deles na infância? João Luís Ceccantini, em 1997, escreveu para o jornal Proleitura um artigo sobre as adaptaçóes de clássicos e afirmou que "a cada adaptação bem realizada de um clássico (nas várias linguagens) é grande o número de leitores que se dirige aos textos originais" (CECCANTINI, 2004, p. 87). Fato este que atestei inúmeras vezes ao longo da minha experiência como professora do Instituto de História da Universidade 
Federal do Rio de Janeiro, quando alunos vinham me abordar para conversar sobre as epopeias homéricas e as tragédias e mostrando que o interesse deles era derivado de eles terem lido quando crianças adaptações desses clássicos.

A adaptação mantém na memória o original, o clássico, mas também gesta mudanças que dialogam com a escrita contemporânea à adaptação (AMORIM, 2005, p. 30).

As inúmeras adaptações, realizadas em momentos bistóricos distintos, concretizam o postulado de que a literatura não se apresenta como uma única resposta para as diferentes perguntas surgidas em cada época, porque tanto o leitor como suas inquietaçóes se modificam. $O$ olhar direcionado para obra busca compreender o presente ou mesmo o passado, mas a sua bistória não é a igual a dos leitores pretéritos, logo as questóes formuladas ao texto serão outras. Cabe ao adaptador, sujeito bistórico do seu tempo, compreender as indagações dos leitores infanto-juvenis e as possibilidades da obra ao ser adaptada de respondê-las (CARVALHO, 2006, p. 18).

Desse modo, é mais profícuo analisar as adaptaçóes como textos que dialogam com seus próprios contextos de produção, não com os contextos de seus originais. Afinal, o autor das adaptações é um sujeito receptor a posteriori, que não está inserido no contexto dos sujeitos destinatários e receptores da época em que o clássico foi composto (o que não impede de procurar saber acerca desse contexto, devendo, inclusive, fazề-lo para que sua adaptação seja de boa qualidade).

\section{5+o Colocando em prática - Algumas breVes SUgestónes}

Por que trabalhar com a Antiguidade Clássica para se falar de etnicidade? Ana Maria Machado, ao falar sobre a literatura clássica, afirma que

Guardada por tanto tempo e reconhecida como um tesouro da bumanidade, a cultura grega antiga sempre despertou o entusiasmo de leitores apaixonados, em diferentes épocas bistóricas. São uma fonte inesgotável, onde sempre podemos beber. Para muita gente, eles são os mais fascinantes de todos os clássicos. Provavelmente são os que mais marcaram toda a cultura ocidental (MACHADO, 2009, p. 26).

Contudo, um outro aspecto preocupa o professor: o da obrigatoriedade da leitura como algo prejudicial ao interesse do aluno. Mário Feijó (2010, p. 14) e Ana Maria Machado (2009, p. 13), ao escreverem sobre a questão da obrigatoriedade da leitura na sala de aula, defendem, cada um, a seu modo, 
que ninguém deve ser obrigado a ler algo de que não goste, uma vez que isso pode - em vez de gerar o efeito pretendido, que é fazer a criança ou o jovem tomar gosto pela leitura - gerar o efeito inverso e fazer com que eles tenham ojeriza à leitura. Teresa Colomer defende essa obrigatoriedade (COLOMER, p. 92 e 93):

[...] na atualidade, aumentam as vozes que defendem a responsabilidade social de oferecer aos meninos e às meninas o acesso a uma tradição cultural compartilhada pela coletividade. Isso requer a criação de um horizonte de leituras "clássicas", entendidas como um conjunto formado pelo folclore, os títulos mais valorizados da literatura infantil e o início da leitura das grandes obras universais (COLOMER, 2017, p. 127).

Contudo, ela também defende que essa literatura não pode ser maçante, levando em consideração sempre os interesses dos alunos, uma vez que eles não são meros receptores dos conhecimentos. Para ela, "os melhores livros são aqueles que estabelecem um compromisso entre o que as crianças podem entender sozinhas e o que podem compreender por meio de um esforço da imaginação que seja suficientemente compensado" (COLOMER, 2017, p. 37).

É fato que os poemas de Homero possuem uma linguagem a qual a criança e o jovem do século XXI podem não conseguir acessar sem mediação. Ana Maria Machado (2009, p. 11 e 12) coloca que

É claro que hoje em dia o ensino é diferente e o mundo é outro. Não se concebe que as crianças sejam postas a estudar latim e grego, ou a ler pesadas versóes completas e originais de livros antigos - como já foi de praxe em várias familias de algumas sociedades há um século. Apenas não precisamos cair no extremo oposto. Ou seja, o de achar que qualquer leitura de clássico pelos jovens perdeu o sentido e, portanto, deve ser abandonada nestes tempos de primazia da imagem e dominio das diferentes telas sobre a palavra impressa em papel.

Assim, a mediação entre os educandos e esses clássicos pode ser feita tanto pelos professores quanto pelas próprias adaptaçóes. Sugerimos, aqui, um trabalho que conjugue ambos: a adaptação caminhando junto com o clássico. A adaptação, sozinha, não dá a dimensão do clássico: é preciso que nós, mediadores, conheçamos bem esse clássico para que consigamos ter um bom aproveitamento das adaptaçóes.

As boas adaptações são aquelas que conseguem manter o mesmo fio condutor da obra original e traga as mesmas imagens marcantes da mesma. Uma adaptação da Odisseia sem o Ciclope, por exemplo, não seria uma boa 
adaptação, uma vez que essa imagem é muito marcante até mesmo dentro da própria obra, como já vimos. Sendo assim, propomos, aqui, dois modos de trabalho com adaptações. Contudo, em ambos os casos, cremos ser necessário trazer um pouco do original para que o aluno tenha dimensão do clássico e como ele foi composto.

Esse trabalho não deve estar inserido no planejamento como se fosse uma mera curiosidade acerca do mundo grego antigo: ele deve dialogar com o conteúdo programático. Isso auxilia o professor nas estratégias de ensino desse conteúdo, bem como faz com que ele aproveite o tempo em sala de aula. Muito se fala da questão da "fata de tempo" para se fazer atividades lúdicas e diferentes com os alunos, mas pouco se fala da inaptidão do professor em conseguir associar essas atividades lúdicas ao próprio ensino do "conteúdo" em si.

De fato, são muitos conteúdos para administrar em pouco tempo; por isso essas atividades que, a priori, seriam tidas como "extraclasse" devem ser incluídas como metodologia mesmo de ensino deles. Um documento (seja ele texto escrito, imagem, filme) não deve ser utilizado para ilustrar um conteúdo, mas para auxiliar na sua compreensão. É possível, também, utilizar esses documentos para avaliaçóes, fazendo com que o aluno relacione o conteúdo com o próprio documento e estimulando-o a pensar acerca da sua própria realidade a partir daquele documento. A avaliação resultante do trabalho com adaptação não deve ser o preenchimento de uma ficha de leitura ou um questionário, pois isso acaba se tornando uma verificação, nos moldes que já discutimos.

Sendo assim, escolhemos duas adaptações para trabalhar de dois modos distintos: a Odisseia adaptada por Marcos Maffei e ilustrada por Eloar Guazzelli Filho para a Coleção Recontar (Escala Educacional, 2004) e Odisseia de Homero (Segundo João Vitor), de Gustavo Piqueira. Em ambos os casos, pensamos atividades para dois tempos de aula. Existem duas opções: pedir para os alunos lerem a adaptação previamente ou lê-la junto com eles em sala de aula, apontando, durante a leitura, o conteúdo programático de Grécia a ser trabalhado.

\subsection{Odisseia de Marcos Maffei e Eloar Guazzelli Filho}

Essa coleção, segundo os editores, foi feita para levar aos pequenos histórias atemporais, que continuam a divertir e ensinar. $\mathrm{O}$ caráter pedagógico da literatura infantil ainda aparece aqui como norte. A Odisseia, especificamente, é dividida em vinte e quatro capítulos, bem como a obra original é dividida em vinte e quatro cantos. 
O intuito do adaptador é resumir os principais acontecimentos da Odisseia sem, contudo, desrespeitar a divisão em cantos feita pelos sábios alexandrinos. Sendo assim, a história segue a narrativa homérica, porém de maneira adaptada à linguagem e à dinâmica da narração em prosa.

O ideal é que o professor leia junto com os alunos a obra e selecione um dos capítulos para trazer o canto original e lê-lo também com os alunos, incentivando-os a compreender as diferenças entre uma narrativa e outra, tanto em relação ao gênero quanto em relação às noções escolhidas para a contagem da história. Nesse momento, é possível introduzir aos alunos os conteúdos relativos à literatura grega, bem como o próprio contexto no qual as epopeias homéricas estão ancoradas (como o próprio processo de formação de apoikíai - "colônias" - gregas ao longo do Mediterrâneo). O professor pode mostrar como cada povo que Odisseu encontra é marcado pela sua presença.

Propomos, aqui, eleger o capítulo 9, referente ao canto IX, o qual relata o encontro de Odisseu com o Ciclope. É um dos capítulos mais extensos do livro e que traz a seguinte caracterização do Ciclope:

Fomos então parar noutra ilha, onde havia água e muitas cabras. Dali se via uma terra que parecia habitada, e no dia seguinte decidi ir até lá só com meu navio. Ancoramos onde havia uma grande caverna. Escolbi doze de meus homens, e fomos até ela, levando odres de vinho, para ter algo a oferecer. Na enorme caverna, havia cestos cheios de queijos, e cercados com filhotes de ovelhas e cabras, mas seu dono levara seus rebanhos para pastar.

Ele não demorou a chegar, com um feixe de lenha tão grande que fez um estrondo ao ser largado no chão, e corremos a nos esconder, pois era um Ciclope, um gigante enorme de um olho só. Ele fechou a caverna com uma pedra imensa e muito pesada, e ao acender o fogo nos viu, e perguntou com sua voz tremenda quem éramos. (MAFFEI, 2004, p. 20).

Aqui, o exagero (no corpo, na voz, nos atos do Ciclope) é reiterado várias vezes, a fim de mostrar a monstruosidade do personagem. A imagem do pelórios é aqui evidente, bem como nas ilustraçóes, que os mostram extremamente gigantes frente aos navios gregos. $\mathrm{O}$ texto continua, de modo a narrar como o Ciclope devora os homens de Odisseu, reiterando a imagem de que ele não é um "homem comedor de pão". Esses são os signos de etnicidade e alteridade que se repetem na adaptação.

No texto de Homero (IX, vv. 176-301), outros elementos se destacam, como a dicotomia entre o cru e o cozido (com a presença da fumaça dos fornos), o desconhecimento das leis, a convivência em comunidade e a ausência 
de amizade ritual. Todos esses elementos têm a ver com a construção da dicotomia entre o grego e seus Outros e, mais tarde, entre o grego e o bárbaro:

A terra dos ciclopes, que perto viviam, observávamos, sua fumaça e o som de ovelhas e cabras.

Quando o sol mergulhou e vieram as trevas, então repousamos na rebentação do mar.

Quando surgiu a nasce-cedo, Aurora dedos-róseos, então eu, realizando assembleia, disse entre eles: 'Os outros, vós aqui ficai, meus leais companheiros; mas eu, com minha nau e meus companheiros, vou verificar esses homens, de que tipo eles são, se desmedidos, selvagens e não civilizados, ou hospitaleiros, com mente que teme o deus'. Dito isso, embarquei e pedi aos companheiros que também embarcassem e os cabos soltassem. Logo embarcaram e sentaram-se junto aos calços, e, alinhados, golpeavam o mar cinzento com remos. Mas ao chegarmos a esse lugar que perto ficava, lá vimos, no extremo, uma caverna junto ao mar, alta, à sombra de loureiros. Lá, grande rebanho, ovelhas e cabras, pernoitava; em torno, cerca alta se construira com blocos de uma pedreira, com grandes pinheiros e carvalhos alta-copa. Lá pernoitava um varão, portentoso, ele que o rebanho, sozinho, apascentava, afastado: aos outros não visitava, mas, longe vivendo, normas ignorava. De fato, era um assombro portentoso, não parecia um varão come-pão, mas um pico matoso dos altos montes, que surge só, longe dos outros. Então aos demais leais companbeiros pedi que lá, junto à nau, ficassem e guardassem a nau; mas eu, após escolher doze nobres companheiros, fui. Levava um odre de cabra com vinho escuro, doce, que me dera Máron, filho de Euantes, sacerdote de Apolo, que zela por Ismaros, porque, junto com filho e esposa, nós o protegemos, venerando-o, pois habitava bosque arvorejado de Febo Apolo. Deu-me presentes radiantes: de ouro bem trabalhado, sete pesos me deu, me deu ânfora toda de prata, e depois vinho em doze ânforas dupla-alça ao todo verteu, doce, puro, bebida divina. A esse ninguém conhecia, nem escravo nem criado, em sua casa, só ele próprio, a cara esposa e uma só governanta. Quando alguém bebesse esse vinho tinto, doce como mel, enchia um cálice e doze medidas de água 
vertia; um doce aroma da ânfora emanava, prodigioso: então impossivel seria abster-se.

Eu trazia um grande odre cheio dele, e também acepipes no alforje: logo meu ânimo orgulboso pensou

que encontraria varão vestido com grande bravura, selvagem, não conbecendo bem tradições nem normas.

Céleres, nos dirigimos ao antro e dentro não o achamos, mas apascentava no pasto gordos rebanhos. Após chegar ao antro, a tudo contemplamos, cestos abarrotados de queijo, cercados repletos de ovelhas e cabritos: separados por categorias, encerrados, à parte os mais velhos, à parte medianos, à parte filhotes. Todas as vasilhas transbordavam de soro, e baldes e tigelas, fabricadas, com as quais ordenhava.

Lá os companbeiros suplicaram-me para, primeiro, pegar algum queijo e voltar, e depois, ligeiro, até a nau veloz, cabritos e ovelhas dos cercados arrastar, e navegar pela água salgada; mas não obedeci (e teria sido muito mais vantajoso) para poder vê-lo, esperando que me desse regalos. Pois, após surgir, não seria amável com os companheiros. Tendo lá aceso o fogo, sacrificamos e também nós comemos parte do queijo e, dentro, o esperamos, sentados, até voltar com ovelhas: trazia ponderoso peso de madeira seca que seria usado para seu jantar. Lançando-o fora do antro, produziu um estrondo; nós, com medo, recuamos até o fundo do antro. Ele à ampla gruta tocou o gordo rebanho, tantas quantas ordenhava, e os machos deixou fora, carneiros e bodes, no exterior, atrás da alta cerca. Então ergueu e pôs na entrada grande rocha, ponderosa: a ela, nem vinte e dois carros ótimos, de quatro rodas, solevariam do solo; tal rochedo, alcantilado, colocou na entrada. Sentado, ordenhava ovelhas e cabras balentes, tudo com adequação, e pôs um filhote sob cada uma. Logo metade do branco leite separou para coalhar e pôs os coalhos, após juntá-los, em cestos trançados; metade lá colocou em barris, para que estivesse disponivel para ele beber em seu jantar.

Mas após ocupar-se de suas tarefas com zelo, então, ao acender o fogo, viu-nos e perguntou: 'Estranhos, quem sois? Donde navegastes por fluentes vias? Acaso devido a um assunto ou, levianos, vagais tal qual piratas ao mar? Esses vagam arriscando suas vidas, levando dano a gentes alheias. Assim falou, e nosso coração rachou-se, 
atemorizados com a voz pesada e o portento em si. Mesmo assim, com palavras respondendo, disse-the: 'Nós, aqueus vindos de Troia, vagamos longe do curso devido a todos os ventos pelo grande abismo de mar

e, ansiando ir para casa, por outra rota, outros percursos, viemos; assim, talvez, Zeus quis armar um plano.

Tropa de Agamêmnon, filho de Atreu, proclamamos ser, desse cuja fama é agora a maior sob o páramo: devastou grande cidade e tropas dilacerou, muitas. Nós, porém, chegando, a esses teus joelhos nos dirigimos, esperando nos hospedares bem ou mesmo dares um regalo, o que é costume entre hóspedes.

Mas respeita os deuses, poderoso; somos teus suplicantes. Zeus é o vingador de suplicantes e hóspedes, o dos-hóspedes, que respeitáveis hóspedes acompanha'. Assim falei, e logo respondeu com impiedoso ânimo: 'És tolo, estrangeiro, ou vieste de longe, tu que me pedes aos deuses temer ou evitar. Os ciclopes não se preocupam com Zeus porta-égide nem com deuses ditosos, pois somos bem mais poderosos; nem eu, para evitar a braveza de Zeus, a ti pouparia ou a teus companheiros se o ânimo não me pedisse. Mas dize-me onde aportaste a nau engenhosa, algures no extremo ou perto, preciso saber'. Assim falou, testando-me, e eu, bem arguto, percebi; respondendo, disse-lhe com palavras ardilosas: 'Minha nau sucumbiu a Posêidon treme-solo; contra rochedo lançou-a nos limites de vossa terra, levando-a rumo ao cabo; vento trouxe-a do mar. Mas eu, com esses ai, escapei do abrupto fim'. Assim falei, e não me respondeu com impiedoso ânimo, mas, de súbito, sobre os companheiros estendeu as mãos, e, tendo dois agarrado, como cachorrinhos ao chão arrojou-os: miolos escorriam no chão e molhavam o solo. Após cortá-los em pedaços, aprontou o jantar; comia-os como leão da montanha, e nada deixou, visceras, carnes e ossos cheios de tutano.

Nós, aos prantos, erguemos os braços a Zeus, vendo o feito terrivel, e a impotência deteve o ânimo. Mas quando o ciclope encheu o grande estômago, após comer carne bumana e, depois, beber leite puro, deitou-se no antro, esticando-se entre o rebanho. Considerei, no enérgico ânimo, dele chegar mais perto, puxar a espada afiada da coxa e golpear no peito onde o diafragma segura of figado, após alcançar com a mão; mas outro ânimo impediu. Lá mesmo também nós nos finaríamos em abrupto fim; da alta entrada, não teríamos conseguido, no braço, 
afastar a ponderosa pedra que lá depositara.

Assim, gemendo, aguardamos a divina Aurora.

Quando surgiu a nasce-cedo, Aurora dedos-róseos,

ele acendeu o fogo e ordenhou esplêndido rebanho,

tudo com adequação, e sob cada fêmea deixou ofilhote.

Mas após ocupar-se de suas tarefas com zelo,

de novo ele agarrou dois de nós e o almoço preparou. ${ }^{8}$

O interessante é, além de destacar esses elementos políticos, econômicos, sociais e culturais da Grécia Antiga, fazer o aluno pensar, instigando-o a reconhecer os elementos de diferenciação entre o grego e o Outro dentro das duas narrativas (a adaptação e o canto IX). Além disso, podemos incitá-lo a uma discussão atual: o que diferencia o brasileiro do estrangeiro hoje? $\mathrm{O}$ que caracteriza a nossa cultura? Qual tem sido a nossa postura em relação aos estrangeiros dentro do nosso país? Nossas fronteiras étnicas são as mesmas dos gregos? Por quê?

\subsection{A Odisseia de Homero (segundo João Vitor)}

O livro de Gustavo Piqueira talvez seja uma das recontagens da Odisseia menos convencionais: com ilustraçóes dele mesmo, traz a história da Odisseia contada pelos olhos de João Vítor, aluno de recuperação do $6^{\circ}$ ano do Ensino Fundamental II (e, pela construção do personagem ao longo da narrativa, de família conservadora e de classe média), que precisa ler esse épico para entregar um trabalho final e conseguir, finalmente passar de ano. O problema é que, em vez de retirar na biblioteca da escola uma adaptação (como fez seu amigo, Fumaça), ele vai com o clássico original para casa.

Ao longo de todo o livro, João Vítor se depara com situações completamente estranhas para ele, que rendem comentários jocosos de sua parte. Em caixa normal, temos a recontagem feita pelo aluno, mas, em negrito e itálico, temos os comentários dele aos episódios que ele narra, o que nos possibilita conhecer a personalidade dele e o mundo em que ele vive. Logo na capa do trabalho (PIQUEIRA, 2013, p. 7), o aluno se vê obrigado a colocar "Resumo e interpretação do livro Odisseia, escrito por Homero da Silva", visto que "na edição que peguei na biblioteca não havia sobrenome do autor, apenas o primeiro nome, Homero. Como todo mundo tem sobrenome, coloquei um bem comum".

Logo na narrativa do Canto I, vemos uma situação que inspira reflexões acerca do etnocentrismo e da alteridade: João Vítor não reconhece o politeísmo 
grego, questionando Homero. Afinal, não existe "Um deus chamado Poseidon", porque "Deus só tem um, e ele se chama Deus mesmo. E seu filho não é nenhum 'ciclope Polifemo', mas Jesus. Que, até o Fumaça sabe, foi crucificado, não cegado" (PIQUEIRA, 2013, p. 16). Adiante (PIQUEIRA, 2013, p. 17), ele reafirma que "pelo visto, neste livro tem um punhado de deuses, então não vou mais discuti, ok? Se Homero da Silva não sabe que só existe um Deus, problema dele. É tarde da noite, tenho o livro inteiro para ler e preciso passar de ano".

Pode parecer, a priori, que é apenas uma criança que desconhece o politeísmo e se vê estranhando a religião do Outro; no entanto, a postura de João Vítor é combativa, reafirmando suas crenças em detrimento da tentativa de contemplação e compreensão do Outro. A ideia de que existe uma religião única e verdadeira denota como o etnocentrismo está entranhado na visão de João Vítor (mesmo que ele não tenha consciência de que está sendo etnocêntrico). É esse tipo de visão preconceituosa (no sentido mesmo do termo, de pré-julgar) que deve ser questionada em sala de aula e levada à reflexão.

No entanto, ao continuar a descrição do Canto I, ele se depara com Athená se transformando em Mentes, um homem, e fica confuso: "Professora, estou na dúvida se chamo Atena de 'o' ou 'a', agora que ela mudou de sexo. $\mathrm{O}$ que devo fazer? Hoje em dia, é um assunto tão delicado, não quero soar preconceituoso" (PIQUEIRA, 2013, p. 17). As questões de gênero são mais palpáveis para João Vítor do que as questões de etnicidade, uma vez que ele tem a sensibilidade de querer saber como ele deveria identificar Athená, que, na sua visão, seria um transgênero. $\mathrm{O}$ adaptador, aqui, mostra que os debates acerca desse tipo de intolerância são mais frequentes na sociedade.

O Canto IX é um dos mais extensos (são 6 páginas escritas e mais 3 de ilustrações). É interessante perceber como a construção da cena do Cíclope se dá de modo diverso em relação às adaptações precedentes e o próprio texto homérico. No livro, João Vítor vê Odisseu como um malfeitor:

Ulisses revela a Alcinoo sua identidade e começa a contar tudo que the aconteceu desde que deixara Troia. Primeiro, deu uma passada em Ísmaro, onde saqueou cidades e chacinou homens, além de tomar mulheres e tesouros, que dividiu com os outros para que ninguém reclamasse. $\mathbf{O u}$ seja: bandido. Não bá outra palavra para definir Ulisses a não ser essa, professora Denise. Ladrão, assassino e sequestrador? Bandido. E o pior, conta seus crimes tranquilão: "Chacinei bomens, levei suas mulberes". Como pode, professora? É muita impunidade, não? Muita. Meus pais vivem comentando sobre isso aqui em casa. Dizem que 
os ricos cometem as maiores barbaridades e sempre se safam. Que moramos no pais do colarinbo branco. Pelo visto, Ulisses também tinba costas quentes. Do contrário, não arriscaria tagarelar por ai suas falcatruas (PIQUEIRA, 2013, p. 62).

O interessante perceber é que aqui, diferentemente da Odisseia original e da adaptação que trabalhamos anteriormente, não há uma tentativa de reforçar as fronteiras étnicas gregas: João Vítor critica o "Greek way of life", pondo em xeque tanto a ideia de civilização dentro do poema quanto a imagem do herói na Grécia Antiga. Como assim ser um herói implica em praticar atitudes que, hoje em dia, seriam condenáveis? Daí a importância de retornar a esse original, a fim de que os alunos compreendam o porquê dessa mudança.

Os ciclopes são descritos como "horríveis gigantes de um olho só" (PIQUEIRA, 2013, p. 63), o Ciclope como um "medonho gigante" (PIQUEIRA, 2013, p. 67) reforçando a ideia da monstruosidade deles. Contudo, João Vítor, ao comentar a atitude do Ciclope de devorar amigos de Odisseu, escreve: "Quem mandou entrar de bico na casa dos outros? Dá nisso..." (PIQUEIRA, 2013, p. 67). As atitudes de Odisseu e de seus companheiros são bastantes questionadas, mostrando o estranhamento do menino em relação à cultura helênica.

Nessa adaptação, podemos chamar a atenção para a própria construção de civilidade dentro de ambas sociedades: a helênica arcaica (em Homero) e a brasileira do século XXI (na adaptação, a realidade de João Vítor), mostrando como mudaram as nossas noções de civilidade, barbaridade e fronteiras étnicas ao longo do tempo histórico. Em vez de uma repulsa ao Ciclope, aqui vemos uma empatia, pautada pelo desconhecimento de João Vítor das fronteiras étnicas helênicas e do ideal de civilização construído por eles com a legitimação dessas fronteiras. Além disso, ela é interessante para discutir a nossa própria relação de alteridade em relação aos gregos, a fim de desconstruir o etnocentrismo presente em nossas concepçóes contemporâneas.

\subsection{Consideraçóes finais}

Em virtude do apresentado, pudemos concluir que é imprescindível abordar conceitos no Ensino da História, a fim de que o aluno possa melhor compreender e modificar de maneira mais efetiva o seu cotidiano. Por isso, defendemos a abordagem do conceito de etnicidade na sala de aula, mas sem antes reforçar que o professor deve, ele mesmo, compreender bem o conceito antes de trabalhar com ele. 
Do mesmo modo, o professor deve conhecer bem os textos clássicos com os quais ele quer trabalhar, mesmo que ele vá utilizar adaptações. Além disso, vemos como é importante a leitura: como Ana Maria Machado (2009, p. 13) colocou, ler é uma forma de resistência, sendo a utilização de textos imprescindível para a formação não somente de um leitor literário, mas de uma pessoa crítica e consciente.

[...] a força educativa da literatura reside, precisamente, no que facilita formas e materiais para essa ampliação de possibilidades: permite estabelecer uma visão distinta sobre o mundo, pôr-se no lugar do outro e ser capaz de adotar uma visão contrária, distanciar-se das palavras usuais ou da realidade em que alguém está imerso e vê-lo como se o contemplasse pela primeira vez (COLOMER, 2017, p. 21).

A boa adaptação, nesse sentido, ajuda a perpetuar na memória o clássico: “Como, então, se dá a real permanência da obra literária? Ora, pela conquista de novos leitores! A adaptação constitui uma estratégia para apresentar a uma nova geração de leitores um discurso literário legitimado pela instituição escolar" (FEIJÓ, 2010, p. 43). Assim como Odisseu, o aluno, ao ler, viaja por mundos Outros, que o faz refletir acerca de sua própria realidade ao conhecer outras realidades.

Utilizar a História Antiga para abordar um conceito tão caro a nós cotidianamente, que vemos nos noticiários as empreitadas dos refugiados para fugirem das guerras e serem recebidos de maneira deplorável em diversos países, as tensóes crescentes entre diversas etnias ao redor do mundo e a nossa própria falta de sensibilidade, às vezes, em compreender o Outro em sua cultura e etnicidade, mostra como, cada vez mais, é necessário retornar ao clássico para pensarmos o contemporâneo. A História Antiga ainda não está ultrapassada.

\begin{abstract}
We propose to think how to enter the ethnicity and ethnocentrism theme in classrooms, by using adaptations of the Antiquity classics. To accomplish this aim, it is necessary to establish some criteria to use this kind of literature, which still generates debates on its profitability, as well as to define ethnicity. We will start with the following concepts: ethnicity (as Fredrik Barth pointed it) and identity-otherness (as Marc Augé does), in order to propose some activities with selected adaptations.
\end{abstract}

Keywords: History Teaching; literary adaptations; ethnicity. 


\section{REFERÊNCIAS}

Documentação textual

HOMERO. Odisseia. Trad. Christian Werner. São Paulo: Cosac Naify, 2014.

\section{Bibliografia}

AMORIM, L. M. Tradução e adaptação: encruzilhadas da textualidade em Alice no País das Maravilhas, de Lewis Carrol, e Kim, de Rudyard Kipling. São Paulo: Editora UNESP, 2005.

AUGÉ, M. A guerra dos sonhos: exercícios de etnoficção. Campinas: Papirus, 1998.

BAILLY, A. Le grand Bailly* Dictionnaire Grec Français. Paris: Hachette, 2000.

BARTH, F. Grupos étnicos e suas fronteiras. In: POUTIGNAT, Ph.; STREIFFFENART, J. Teorias da Etnicidade. Seguido de Grupos étnicos e suas fronteiras de Fredrik Barth. São Paulo: Ed. UNESP, 1998, p. 187-227.

BRASIL. Parâmetros Curriculares Nacionais: Terceiro e Quarto Ciclos do Ensino Fundamental. História. Brasília: MEC / SEF, 1998.

CALVINO, I. Por que ler os clássicos. São Paulo: Cia das Letras, 2007.

CARVALHO, Diógenes Buenos Aires de. A adaptação literária para crianças e jovens: Robinson Crusoé no Brasil. (Tese de Doutorado). Porto Alegre: PUCRS, 2006. v. 1.

CECCANTINI, J. L. C. T. A adaptação dos clássicos. In: BENITES, S. A. L; PEREIRA, R. F. (Orgs.). À roda da leitura: língua e literatura no jornal Proleitura. São Paulo: Cultura Acadêmica; Assis: ANEP, 2004, p. 84-89.

CHANTRAINE, P. Dictionnaire étymologique de la langue Grecque: histoire des mots - tome I. Paris: Éditions Klincksieck, 1968.

COLOMER, T. Introdução à literatura infantil e juvenil atual. São Paulo: Global, 2017.

FEIJÓ, M. O prazer da leitura: como a adaptação de clássicos ajuda a formar leitores. São Paulo: Ática, 2010.

GAMBIER, Y. Adaptation : une ambiguïté a interroger. Meta, Montréal, v. 27, n. 3, p. 421-425, set. 1992.

LUCKESI, C. C. Verificação ou avaliação: o que pratica a escola? In: Avaliação da aprendizagem escolar: estudos e proposições. São Paulo: Cortez, 2008[1994], p. 85-102.

LUVIZOTTO, C. K. Etnicidade e identidade étnica. In: . Cultura gaúcha e separatismo no Rio Grande do Sul. São Paulo: Editora UNESP, 2009, p. 29-36.

MACHADO, A. M. Como e por que ler os clássicos universais desde cedo. Rio de Janeiro: Objetiva, 2009 [2002].

MAFFEI, M. Odisseia. São Paulo: Escala Educacional, 2004. 
MALTA, A. A selvagem perdiçãoः erro e ruína na Ilíada. São Paulo: Odysseus Editora, 2006.

MEIRELES, C. Problemas da literatura infantil. São Paulo: Global, 2016 [1951]. MICELI, P. Uma pedagogia da História? In: PINSKY, J. (Org.). O Ensino de

História e a criação do fato. São Paulo: Contexto, 2017, p. 37-52.

MUGLER, Ch. L'«altérité» chez Homère. Revue des Études Grecques, Paris, tomo 82, fasc. 389-390, p. 1-13, jan./jun. 1969.

NADAI, E. O ensino de História e a "pedagogia do cidadão". In: PINSKY, J. (Org.). O Ensino de História e a criação do fato. São Paulo: Contexto, 2017, p. 27-35.

PIQUEIRA, G. Odisseia de Homero (segundo João Vítor). São Paulo: Editora Gaivota, 2013.

POUTIGNAT, Ph.; STREIFF-FENART, J. Teorias da etnicidade. Seguido de Grupos étnicos e suas fronteiras de Fredrik Barth. São Paulo: Ed. UNESP, 1998. 